\title{
The Pattern of Information Structure in Junior High School Students in Informal and Formal Conversations
}

\author{
Aprilia Rosmarie \\ Universitas Diponegoro, Jl. Prof. Sudarto No.13, Tembalang, Semarang, 50275 Indonesia \\ rose15494@yahoo.com \\ corresponding author
}

\begin{abstract}
\begin{tabular}{l|l} 
ARTICLE INFO ABSTRACT & ART
\end{tabular}
Article history

Received 04, 19, 2020

Revised 8, 10, 2020

Accepted 10, 22, 2020

Keywords

Information structure

Pattern

Informal conversation

Formal conversation

Since language is used as a communication tool, information structure is essential in a language system and in the communication process. This research was aimed to find out the pattern of information structure in the conversations of junior high school students. The present research focused on informal and conversations between student-student and teacher-student or student-teacher conversations. The research portrayed thirty-six informal and formal conversations. This was qualitative research, and the researcher focused on Topic and Focus of each conversation, since topic and focus are important constructions in giving the information or constructing the sentence. The findings of this study portrayed that both speakers (teacher or students) tended to eliminate the subject, or the TOPIC (47\%), while only $33 \%$ of eliminating the predicate or the FOCUS, and the rest is only $20 \%$ showed that there was no any elimination in the conversations. Meanwhile, in the informal conversation, both of speakers (teacher or students) tended to eliminate the subject, or the TOPIC $(60 \%)$, while only $27 \%$ of eliminating the predicate or the FOCUS, and the rest is only $13 \%$ showed that there was no any elimination in the conversations.

Sejak bahasa sebagai alat komunikasi, oleh sebab sebab itu struktur informasi sangat penting dalam sistem bahasa dan dalam proses komunikasi. Penelitian ini bertujuan untuk mengetahui pola struktur informasi pada siswa SMP, di salah satu SMP di sekolah swasta di Semarang. Peneliti fokus pada pembicaraan informal dan antara siswa-siswa dan guru-siswa atau siswa-guru. Peneliti mendapat tiga puluh enam percakapan percakapan formal dan informal. Ini adalah penelitian kualitatif dan peneliti fokus pada Topik dan Fokus dari setiap percakapan, karena topik dan fokus adalah konstruksi penting dalam memberikan informasi atau menyusun kalimat. Akibatnya, dalam percakapan formal, baik penutur (guru atau siswa) cenderung untuk menghilangkan subjek, atau TOPIC (47\%), sementara hanya $33 \%$ dari menghilangkan predikat atau FOKUS, dan sisanya hanya $20 \%$ menunjukkan bahwa tidak ada eliminasi dalam percakapan. Sementara itu, dalam percakapan informal, baik penutur (guru atau siswa) cenderung untuk menghilangkan subjek, atau TOPIC $(60 \%)$, sedangkan hanya $27 \%$ dari menghilangkan predikat atau FOKUS, dan sisanya hanya $13 \%$ menunjukkan bahwa tidak ada eliminasi dalam percakapan
\end{abstract}

This is an open access article under the $\mathrm{CC}-\mathrm{BY}$ license.

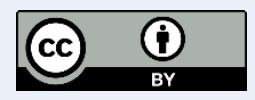

\section{Introduction}

Language is an important tool in communication. Language can develop itself if there is contact with other languages. Language is unique. It means that each language has its own characteristics such as differences in sound, phoneme, word formation system, or in sentence formation system. The study of language is called linguistics.

One example of developments in linguistics is Lexical Functional Grammar (LFG). It existed in late 1970 and was introduced by (Kaplan \& Bresnan, 1995). (Dalrymple, 2001) defined this approach about linguistic structure and re- 
lations. Lexical Functional Grammar is described in parallel representations that have related each other. Lexical Functional Grammar analyses sentences in terms of four parallels representations, namely 1) constituent structures (c-structures), 2) functional structures (f-structures), c) a-structure, and d) semantic structure. Information structure belongs to discourse function (DF) that has two elements, such as topic and focus.

Furthermore, (Arka, 2003) stated that Lexical Functional Grammar or LFG is part of generative grammar. Lexical Functional Grammar (LFG) is a generative grammar based on the lexicon. The difference with other grammars is that Lexical Functional Grammar (LFG) does not use the notion of transformation. Lexical Functional Grammar (LFG) has two parts based on the mapping theory. The first part is related to the argument structure, semantic structure, and functional structure. The second part is mapping with respect to constituent structures (c-structures) and functional structures (f-structures).

Previous research has reported that information structure encompasses focus and topic constructions. The function is to describe every sentence and to find out typology (Arka, 2003; Dalrymple, 1993, 2001; Kaplan \& Bresnan, 1995). To analyze a discourse or conversation, the researcher used information structure. (Birner \& Ward, 2006) stated that information structure concerns how information in discourse is packaged and how a syntactic structure is used in a particular context while another structure is avoided. As the research questions, the researcher tried to formulate the research question:

RQ1. What is the pattern of information structure in Junior High School Students (JHS) in an informal and formal conversation?

The aim of this research was to investigate the pattern of information structure that had been uttered by Junior High School (JHS) students, especially in their informal and formal conversation.

\section{Literature Review}

Linguistics is a study about language. (Andre, 1960) said that its studies language form, language meaning, and language in context. Language itself is a means of communication tool that we use to interact and communicate with others. Many approaches included in the schools of linguistics such as structuralism, Lexical Functional Grammar (LFG), Transformational Grammar, Systemic Functional Grammar (SFL), Prague Schools, etc.

One of the schools of linguistics is Lexical Functional Grammar (LFG). It existed in late 1970 and was introduced by (Kaplan \& Bresnan, 1995). This approach studied linguistic structure and the relations as defined by (Dalrymple, 2001). In Lexical Functional Grammar (LFG), there are constituent structure and functional structure. Both belong to the classic theory of Lexical Functional Grammar (LFG). The function is to describe every sentence in the world and to find out typology (Arka, 2003; Dalrymple, 1993, 2001; Kaplan \& Bresnan, 1995).

Information structure has 'TOPIC' or abbreviated as 'TOP', which means "A topic is what a given clause or sentence is about ....", as defined by (Obata, 2003). Further, (Verschueren et al., 1995) said that "topics must be referential; they refer to entities, events, states of the affair, and so on. "Another part in information structure instead of TOPIC is 'FOCUS' or commonly known as 'FOC'. Focus gave new information that is assumed to be presupposed and important (Schneider, 2009). Further, she added that people should distinguish and differentiate between topic and focus; they are totally different. Focus gave new information meanwhile the topic is presupposed.

The advantages of using this theory instead of as a tool to analyze verbal sentences in Indonesia are Lexical Functional Grammar (LFG) is more detailed and has a complete explanation. (Liamkina \& Ryshina - Pankova, 2012) stated that using this approach can be a rich resource in teaching grammar in making contextualized meaning in a culture- and language specific way. Meanwhile, the structuralism approach only emphasized segmentation and phonemics and excluded meaning as cited by (Widdowson, 2007) based on Firth's 1957explanation in his journal.

(Puspitasari, 2019) agreed that the structural approach has an advantage in creating and designing a textbook because this approach gave a wide description. Further, she added that this approach could be an alternative in principle learning in language conservative.

The researcher concluded some previous studies that used Lexical Functional Grammar (LFG) in their research. The first study was 
done by (Jufrizal et al., 2009), who did a typology analysis of the Minangkabaunese language clause. They analyzed the information structure and got three clauses such as active clause, passive clause, and topicalization clause. These three clauses were mostly uttered by Minangkabaunese.

Furthermore, (Cholisi, 2013) agreed that Lexical Functional Grammar (LFG) Theory could be a tool to analyze verbal sentences in Indonesian. (Cholisi, 2013) added that the Indonesian verb structure always related to adjunct and oblique objects. Then, (Kosmas, 2015) used this Lexical Functional Grammar (LFG) Theory, especially in constituent structure and functional structure, to analyze the passive construction in the Manggarai language. And as a result, (Kosmas, 2015) found that the Manggarai language is passive syntactic construction because this language does not have a phonological marker.

(Romadhan, 2019) also did X-Comp analysis in the Indonesian language using Lexical Functional Grammar, and there was destruction of arguments in the embedded verbs in $\mathrm{X}$ Comp. In this research, the researcher tried to analyze and find out the pattern of information structure in Junior High School (JHS) Students both in informal and formal conversation.

\section{Method}

This research employed a descriptive qualitative approach. (Fraenkel et al., 1993) stated that qualitative research is an approach that investigates the quality of relationships, activities, situations, or materials. (Fraenkel et al., 1993) added that the descriptive method is a method used to explain, analyze, and classify something by doing surveys, questionnaires, observation, and text.

For the research design, the researcher used the grounded theory. (Bryant \& Charmaz, 2007) explained that the grounded theory strategies enable researchers write memos or notes, record, identify, and sort or classify the data based on the observation.

Participants involved in this study were 12 junior high school students. The focus of this research is the informal and formal conversations enacted between student and student, or student and teacher, or teacher-student while they were having a class. To avoid subjectivity, the researcher's paradox in this research was ensured by the teacher's and students' natural conversations.
The researcher obtained thirty-six conversations that would be used to find out the pattern of the information structure in these conversations. Then, after collecting the data, the researcher analyzed the information structure based on its TOPIC or FOCUS then the researcher concluded the pattern of the conversations into a text. Text means part of communication, which forms a meaningful context (Marmorstein, 2018). He added that the text contains paragraphs, complex sentences, and simple clauses. Further, Halliday and Hasan defined as cited in (Marmorstein, 2018) book. They mentioned that text is not just a sentence cluster but a unit of language in use, a unified whole.

\section{Results and Discussion}

Lexical Functional Grammar (LFG) has some grained components such as background, given, focus and topic within the i-structure projection (Butt \& King, 2014). This information structure is different between the constituent structure since its morphological markings. And in this research, the researcher tried to observe one school of Junior High School in Semarang. The researcher intended to find out the information structure in informal conversation (student and student) and informal conversation (student and teacher/ and student).

The researcher got eighteen conversations for each. The conversations were written in Indonesian because it should be pure and natural, using the native language. The Mother tongue itself means the first language that the child acquired (Dardjowidjojo, 2003). (Kurniati, 2015) found that using the mother tongue in teaching can help the students develop and understand the lesson.

Another research was conducted by (Suhardin et al., 2018). They got that there is a relationship between students' language acquisition and students' motivation in learning. It showed that the students' motivation itself could construct a good atmosphere in learning. Further, (Li, 2009) stated that learning motivation is a strong internal drive for language learning. Look at the first example in this informal conversation below:

Student A: Ada apa Nora? (What is wrong Nora?)

Student B: Dapat nilai buruk. (Got bad score.) 
The information structure (Str-i) found by Halliday, and this structure means that the conversation above is as follows an oral sentence that depends on a number of constituents in syntax and is related to the emphasis of the phrase on the sentence. (Widayati, 2005) summarizes that in the structure of this information can put a predicate or object or information at the beginning of a sentence, or another name is an inversion sentence as in the following example:

$$
\begin{aligned}
& \text { Str-I a.1: Top (Nora) } \\
& \text { Fok (Q-Ada apa) b.2: Top ( ) } \\
& \text { Fok (Dapat) Nilai buruk }
\end{aligned}
$$

The terms TOP, which means TOPIC and FOK, which means FOCUS is one of the naming terms used in the structure of information (Str-i) and included in the Prague view (Widayati, 2005). The topic itself is information that has been given (given information), while Focus is the new information that has been added (new information). Characteristics are the existence of a subject, the predicate of all sentences analyzed. If we look at the example above, the first FOK (Focus) is found in the word 'what is it' then reinforced or emphasized by the next sentence, which is 'get' 'bad score'. This gives new information in accordance with the previous sentence. And in a.2 TOP (Topic) experienced a lapse.

Meanwhile, the example of a formal conversation between student and teacher is written below:

Student: Apa yang harus saya lakukan bu? (What should I do, Ma'am?)

\section{Teacher: Baca dahulu. (Read first.)}

Str-I b.1: $\quad$ Top (Saya)

Fok (Q- apa yang harus dilakukan)

$$
\begin{array}{ll}
\text { b.2: } & \text { Top ( ) } \\
& \text { Fok (baca dahulu) }
\end{array}
$$

The example above has the same pattern as the previous conversation. The second speaker loved eliminating the subject and using the predicate directly even though the subject is eliminated. The important elements of the sentence are subject and predicate. And the information structure is grammatically on the sentences. If the sentence does not have a subject, at least the hearer will still understand the topic or the information of the sentence and vice ver$\mathrm{sa}$, if the predicate is not existed but the subject still exists, the hearer still could understand the context or topic of the sentence.

The researcher observed that there is a sentence which is not having elimination, both subject, and predicate elimination. The researcher illustrated and explained below:

Student: Latar itu apa bu? (What is setting Ma'am?)

Teacher: Latar dibagi dua, tempat dan waktu. (Setting is divided into two parts, place and time.)

In this case, the researcher argued that there is no elimination of neither subject elimination nor predicate elimination. Both speakers could utter full information. (Lambrecht, 1996) explained that information structure is the grammatical component of the sentence in which the proposition as a conceptual embodiment of circumstances paired with lexicogrammatically structures in relation to the mental state of the talkative use and interpret these structures as units of information in the context of a particular discourse.

As a comparison, (Butt \& King, 2014) also did an investigation on the question and information structure in Urdu/Hindi. She focused on the Wh- question and polar question. But, in this research, the questions that had been used mostly in the ungrammatical pattern. The re-

\begin{tabular}{|c|c|c|}
\hline No. & $\begin{array}{l}\text { Conversations (in } \\
\text { Indonesian lan- } \\
\text { guage) }\end{array}$ & Pattern \\
\hline 1. & $\begin{array}{l}\text { S: Apa yang harus saya } \\
\text { lakukan bu? (What } \\
\text { should I do Ma'am?) } \\
\text { T: Baca dahulu. ( Read } \\
\text { first.) }\end{array}$ & $\begin{array}{l}\text { Subject elimination } \\
\text { Based on the } \\
\text { teacher' utterance, } \\
\text { she eliminated the } \\
\text { subject (TOPIC) in } \\
\text { here. The subject } \\
\text { was 'SAYA' or 'the } \\
\text { student' }\end{array}$ \\
\hline 2. & $\begin{array}{l}\text { T: Gunanya teks narasi } \\
\text { itu untuk? } \\
\quad \text { ( The function of } \\
\text { narrative text is for?) } \\
\text { S: Untuk menghibur. } \\
\quad \text { ( To entertain. ) }\end{array}$ & $\begin{array}{l}\text { Subject elimination } \\
\text { Based on the } \\
\text { student' utterance, } \\
\text { she just eliminated } \\
\text { the subject (TOPIC) } \\
\text { in here. The TOPIC } \\
\text { is the narrative text. }\end{array}$ \\
\hline 3. & $\begin{array}{l}\text { S: Latar itu apa bu? } \\
\text { ( What is setting } \\
\text { Ma'am? ) } \\
\text { T: Latar dibagi dua, } \\
\text { tempat dan waktu. } \\
\text { ( Setting is divided } \\
\text { into two parts, place }\end{array}$ & $\begin{array}{l}\text { No any elimination } \\
\text { In this case, the } \\
\text { researcher argued } \\
\text { that there is no any } \\
\text { elimination neither } \\
\text { subject elimination } \\
\text { nor predicate }\end{array}$ \\
\hline
\end{tabular}
searcher would like to illustrate some example in this Table 1.

Table 1. Investigation on the question and information structure in Urdu/Hindi 


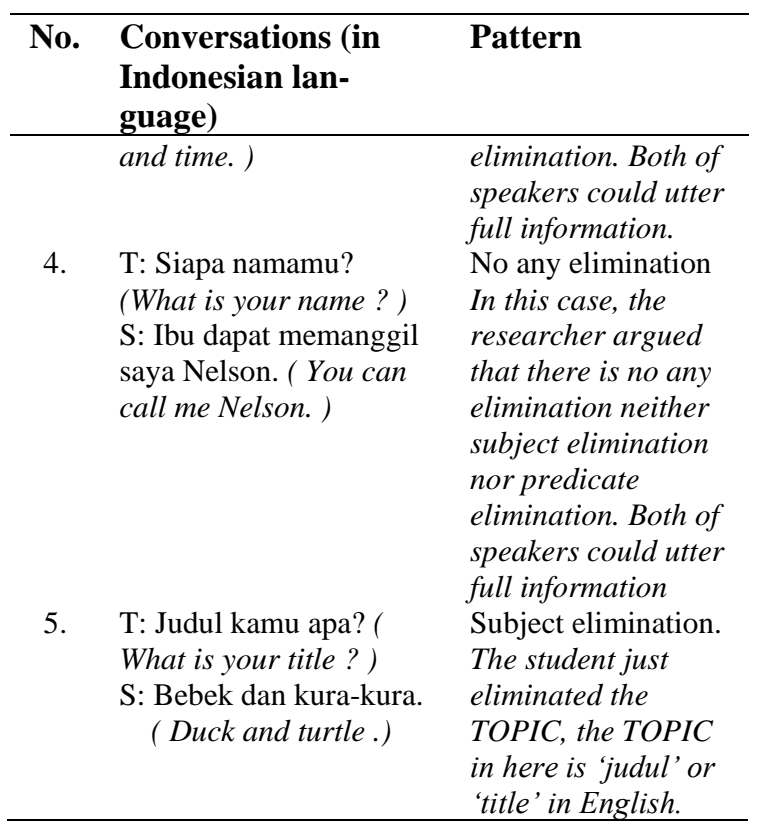

Based on the data, the researcher may conclude that informal conversation, both of speakers (teacher or students) tended to eliminate the subject, or the Topic (47\%), while only $33 \%$ of eliminating the predicate or the Focus, and the rest is only $20 \%$ showed that there was not any elimination in the conversations. Then, the researcher would give some examples of utterance that uttered in informal conversation shows in Table 2:

Table 2. Researcher would give some ex $\neg$ amples of utterance that uttered in informal conversation

\begin{tabular}{|c|c|c|}
\hline No. & $\begin{array}{l}\text { Conversations } \\
\text { (in Indonesian) }\end{array}$ & Pattern \\
\hline 1. & $\begin{array}{l}\text { S1: Ada apa Nora? } \\
\text { ( What is wrong } \\
\text { Nora? ) } \\
\text { S2: Dapat nilai } \\
\text { buruk. ( Got bad } \\
\text { score.) }\end{array}$ & $\begin{array}{l}\text { Subject elimination } \\
\text { The second student } \\
\text { just eliminated the } \\
\text { subject, and directly } \\
\text { told to the first } \\
\text { speaker that she got a } \\
\text { bad score. }\end{array}$ \\
\hline 2. & $\begin{array}{l}\text { S1: PR nya tentang } \\
\text { apa? (What is your } \\
\text { homework about? } \\
\text { ) } \\
\text { S2: Aktif dan } \\
\text { pasif. (Active and } \\
\text { passive.) }\end{array}$ & $\begin{array}{l}\text { Predicate Elimination } \\
\text { The speaker just } \\
\text { eliminated the } \\
\text { predicate, the } \\
\text { information given is } \\
\text { not completed yet } \\
\text { since the second } \\
\text { speaker only told the } \\
\text { theme of the } \\
\text { homework and not } \\
\text { telling how to do on it. }\end{array}$ \\
\hline 3. & $\begin{array}{l}\text { S1: Jadi apa sih isi } \\
\text { tas itu? } \\
\text { ( So, what is the } \\
\text { content of the bag } \\
\text { ?) } \\
\text { S2: Eh, buku dan } \\
\text { semacamnya. }\end{array}$ & $\begin{array}{l}\text { Subject elimination. } \\
\text { The speaker } \\
\text { eliminated the } \\
\text { FOCUS, the FOCUS } \\
\text { in here is the 'bag' or } \\
\text { 'isi tas'. }\end{array}$ \\
\hline
\end{tabular}

\begin{tabular}{|c|c|c|}
\hline No. & $\begin{array}{l}\text { Conversations } \\
\text { (in Indonesian) }\end{array}$ & Pattern \\
\hline 4. & $\begin{array}{l}\quad \text { (Mm, book } \\
\text { and so on.) } \\
\text { S1: Di orientasinya } \\
\text { cari apa? } \\
\text { (What should we } \\
\text { find in } \\
\text { orientation?) } \\
\text { S2: Ya cari tokoh, } \\
\text { latar, waktu. } \\
\text { (Yeah, find out the } \\
\text { characters, setting, } \\
\text { and time.) }\end{array}$ & $\begin{array}{l}\text { No any elimination } \\
\text { Based on this short } \\
\text { conversation, the } \\
\text { researcher did not find } \\
\text { any elimination } \\
\text { neither subject } \\
\text { elimination nor } \\
\text { predicate elimination } \\
\text { in this conversation. }\end{array}$ \\
\hline 5. & $\begin{array}{l}\text { S1: Danaunya } \\
\text { kenapa kering? } \\
\quad \text { ( Why does the } \\
\text { lake dry?) } \\
\text { S2: Tak hujan } \\
\text { setaun. } \\
\quad \text { ( There is no } \\
\text { rain over a year.) }\end{array}$ & $\begin{array}{l}\text { Subject elimination. } \\
\text { The speaker } \\
\text { eliminated the } \\
\text { FOCUS, the FOCUS } \\
\text { or the subject in here } \\
\text { is the 'lake' or } \\
\text { 'danau'. }\end{array}$ \\
\hline
\end{tabular}

Based on the data, the researcher may conclude that in informal conversation, both of speakers (teacher or students) tended to eliminate the subject, or the Topic (60\%), while only $27 \%$ of eliminating the predicate or the Focus, and the rest is only $13 \%$ showed that there was not any elimination in the conversations.

Thus, based on the result, the researcher may conclude that the speakers in formal or informal conversations loved to eliminate the FOCUS or the Subject. The researcher argued maybe to make it more efficient and simpler in uttering the sentences if the hearer could understand the context by the first speaker. Even though there were some example that had predicate elimination no extension conversation between them was seen.

\section{Conclusion}

The results of this research show that the structure of information is important in language systems and communication processes. This is because we obtain information without language with all its completeness, information will be difficult or impossible for humans to obtain. Therefore, the following conclusions are obtained: a) Informal conversations, both speakers (teachers or students) tend to eliminate subjects or TOPIC (47\%), while only 33\% eliminate predicate or FOCUS, and the remaining $20 \%$ indicates that there is no elimination in conversation; b) In informal conversations, both speakers (teacher or student) tended to omit subjects, or TOPIC $(60 \%)$, while only 
$27 \%$ omitted predicate or FOCUS, and the remaining only $13 \%$. indicates that there are no eliminations in the conversation. Based on the research results, it is suggested to the next researcher to look for information on other structures in a different area, in a different scope, or those future researchers may have constituents or functional structures to complement and add to the data.

\section{References}

Andre, M. (1960). Elements of general linguistics. Faber \& Faber.

Arka, I. W. (2003). Tata bahasa leksikalfungsional (Lexical-Functional Grammar): Prinsip-prinsip utama dan tantangannya bagi analisis bahasa Nusantara. Pelba, 16, 51-105.

Birner, B., \& Ward, G. (2006). Drawing the boundaries of meaning. In Amsterdam: Benjamins. John Benjamin Publishing.

Bryant, A., \& Charmaz, K. (2007). The Sage handbook of grounded theory. Sage.

Butt, M., \& King, T. H. (2014). Questions and information structure in Urdu/Hindi. Proceedings of the LFG14 Conference, 158-178.

Cholisi, F. (2013). A lexical-functional grammar representation of indonesian verbal sentences. Jurnal Sosial Humaniora (JSH), 6(1), 46-61.

Dalrymple, M. (1993). The syntax of anaphoric binding (Issue 36). Center for the Study of Language (CSLI).

Dalrymple, M. (2001). Lexical functional grammar, syntax and semantics. San Diego: Academic Press.

Dardjowidjojo, S. (2003). Psikolinguistik: Pengantar pemahaman bahasa manusia. Yayasan Pustaka Obor Indonesia.

Fraenkel, J. R., Wallen, N. E., \& Hyun, H. H. (1993). How to design and evaluate research in education (2nd ed., Vol. 7). McGraw-Hill New York.

Jufrizal, J., Rusdi, R., \& Refnita, L. (2009). Struktur informasi pada klausa bahasa minangkabau sebuah telaah tipologi grammatical dan struktur informasi. Lingua Didaktika: Jurnal Bahasa Dan Pembelajaran Bahasa, 2(2), 59-69.

Kaplan, R. M., \& Bresnan, J. (1995). Formal system for grammatical representation. In Formal Issues in Lexical-Functional Grammar (Issue 47). Center for the Study of Language (CSLI).

Kosmas, J. (2015). Konstruksi pasif bahasa manggarai: Sebuah analisis leksikalfungsional. RETORIKA: Jurnal Ilmu Bahasa, 1(1), 108-122.
Kurniati, L. (2015). Bahasa ibu dalam pembelajaran anak di sekolah. Jurnal Pesona, 1(1).

Lambrecht, K. (1996). Information structure and sentence form: Topic, focus, and the mental representations of discourse referents (Vol. 71). Cambridge university press.

Li, C. (2009). A Research on second language acquisition and college english teaching. English Language Teaching, 2(4), 57-60.

Liamkina, O., \& Ryshina-Pankova, M. A. R. I. A. N. N. A. (2012). Grammar dilemma: Teaching grammar as a resource for making meaning. The Modern Language Journal, 96(2), 270-289.

Marmorstein, M. (2018). Tense and text in classical arabic: A discourse-oriented study of the classical arabic tense system. Brill.

Obata, K. (2003). A grammar of Bilua: A Papuan language of the Solomon Islands. Pacific Linguistics, Research School of Pacific and Asian Studies, The ....

Puspitasari, Y. (2019). Analisis penerapan linguistik struktural dalam buku teks bahasa Indonesia tingkat SMP/Mts kelas VI. Lingua, 15(2), 125-134.

Romadhan, A. D. (2019). X-komp bahasa indonesia: analisis tata bahasa leksikal fungsional. Edukasia: Jurnal Pendidikan, $6(1), 26-29$.

Schneider, C. (2009). Information structure in Abma. Oceanic Linguistics, 48(1), 1-35.

Shen, P., \& Yodkhumlue, B. (2012). Teacher's questioning and students' critical thinking in college EFL reading classroom. The 8th International Postgraduate Research Colloquium: Interdisciplinary Approach for Enhancing Quality of Life IPRC Proceedings (Online) Available at: Bsris. Swu. Ac. Th/Iprc/8th/044_53_9_Pingshen. Pdf, Retrieved, 17.

Suhardin, S., Juliangkary, E., \& Agusfianuddin, A. (2018). Pengaruh penggunaan bahasa ibu dalam konteks belajar mengajar matematika terhadap daya serap dan motivasi belajar siswa kelas viii Smp Negeri 1 Ropang tahun pelajaran 2016/2017. Media Pendidikan Matematika, 5(1), 33-38.

Verschueren, J., Östman, J., \& Blommaert, J. (1995). Handbook of pragmatics. John Benjamins.

Weimer, M. (2014). The Relationship between Participation and Discussion.

Widayati, D. (2005). Model awal dan model klasik struktur informasi. Logat: Jurnal Ilmiah Bahasa Dan Sastra, 1(2), 73-80. 
Widdowson, H. (2007). Jr firth, 1957, papers in linguistics 1934-51. International Journal of Applied Linguistics, 17(3), 402-413. 